DOI: $10.24234 /$ wisdom.v18i2.480

Nina KRAVCHENKO,

Elena KARPENKO,

Anna MATIIENKO-SILNYTSKA,

Olga VASYLIEVA

\title{
CATEGORY OF SACREDNESS IN THE DISCOURSE OF THE ENGLISH SERMON
} (Theolinguistic Approach)

\begin{abstract}
The present paper deals with investigating the category of the sacredness of the English religious preaching discourse, considered from the standpoint of theolinguistics. It has been proved that being a secondary form of sacred texts, the text of the sermon demonstrates the frequent use of the sacral vocabulary of different groups: limited conceptual and terminological vocabulary, which has religious sense and meanings, borrowings from sacred texts (the so-called biblicisms), and vocabulary of everyday communication, which in the context of preaching becomes religious, and is included in the semantic field of religion on this basis. Different perception of nature and ways to realize the sermon in the Anglican and NeoProtestant churches is manifested in the peculiarities of the attitude towards the sacrality of the Word. The process of desacralization of the sermon, recorded in the Neo-Protestant sermons, occurs due to the contrasting use of sacred vocabulary in a stylistically reduced context, on the one hand, and the use of profane vocabulary to nominate sacred phenomena, on the other.
\end{abstract}

Keywords: preaching discourse, theolinguistics, sermon, category of sacredness, sacral vocabulary.

Introduction

Many linguists' interest in religious issues in the recent decades has caused the emergence of theolinguistics as a new research area in linguistics. In the most general sense, theolinguistics is determined by the research material and develops within the modern anthropocentric paradigm. Structural-semantic linguistic analysis performed on the material of a religious text and provided with a theological commentary is recognized as being theolinguistic.

The term "theolinguistics" first appeared in linguistic papers in 1976. Belgian scholar, professor of the Department of English Linguistics at the University of Brussels (Université Libre de Bruxelles) Jean-Pierre van Noppen is commonly believed to be the founder of theolinguistics; he then argued that theolinguistics is a section of linguistics aiming "to describe how a human word can be applied to God, as well as how a language functions in religious situations, those that do not conform with the rigid standards of direct one-sided communication" (van Noppen, 2006). However, according to E. Kucharska-Dreiss $(2004$, p. 27), this meaning of the term appears very different from the definitions formulated later. The term theolinguistics owes its further spread to the efforts of D. Crystal (2003), who included the article "Theolinguistics" in his "The Cambridge Encyclopedia of Language" in 1987 (p. 463). After the publication of the encyclopedia, theolinguistics as a discipline studying the language of theologians and other persons dealing with the theory and practice of religion, as well as the language of believers, develops in the works of German researchers. They have addressed various issues related to the language of 
religion, namely German religious vocabulary's historical formation and stages of its evolution, the religious language's basic characteristics (Moser, 2019); textual-linguistic analysis of the New Testament texts, linguistic aspects of homiletics (Gössman, 2002); speech acts in the context of worship (Block, 2014), etc. A. Wagner's (1999) work, which outlines two perspectives of the new discipline, namely linguistic and theological ones, is generally considered to be the program article declaring the fruitfulness of the potential interaction between theology and linguistics (p. 509). Theolinguistics in the study of Slavic languages did not gather momentum until the eve of the XXI century, in line with the tendency of "integration of theological knowledge into worldview and culture", which is being increasingly manifested in the modern world (Nazarov, 2004, p. 5). Ukrainian (O. K. Gadomsky), Serbian (K. Koncharevich), Polish (E. Kucharska-Dreiss), and Russian (S. I. Shamarov) researchers contributed to the spread of theolinguistics as a section of linguistics.

Slavic linguistics adopted the idea of establishing theolinguistics as an independent sphere of knowledge relatively recently. Several approaches to the understanding of this discipline's goals and objectives have been formulated by this stage of its formation:

1. the theolinguistics's basic objective lies in the study of the role of the language of religion in society (particularly, in the life of religious groups, such as the Church, denomination, sect and cult) (Koncharevich, 2012, p. 15);

2. the main task of theolinguistics is to "study "religious language" both in the narrow and broad sense of the term" (Gadomsky, 2005, p. 18);

3. its key target is seen in establishing a mediating link between linguistics and theology, which would operate as an intermediate link between religion and church, on the one hand, and society, the state, on the other (Shamarova, 2012, pp. 27-35).

The category of sacredness, interpreted as one of the conceptual categories of anthropocentric orientation, is studied by theolinguistics, among other specific categories inherent in the religious discourse (Malinovich, 1998).

To trace the peculiarities of the sacredness category in Anglican and Neo-Protestant sermons is viewed as the objective of this study.

The object of the study is oral English religious discourse in its preaching realization.

The subject of the research is the category of the sacredness of the English religious preaching discourse, considered from the standpoint of theolinguistics.

The factual material under research is represented by video records of 72 Anglican sermons and 68 Protestant isolated sermons (transcripts of 540 and 620 pages respectively, in A4 size 14 Times New Roman front).

\section{The Category of Sacredness}

Prior to the actual analysis of the linguistic means for the realization of sacredness in the texts of the preaching discourse in question, it appears appropriate to remind the definition of "sacredness". Sacral (from Latin sacer - sacred, holy) means sacred, one that serves religious purposes; concerning the sacred, religious. Dictionaries offer the following definitions: Sacral relating to sacred rites or observances; ritual. The definition analysis of the token sacral demonstrates the importance of such semantic components as rite and observance = ritual, ceremony. Rite $=$ prescribed or customary form of conducting a religious ceremony; observance $=$ a customary rite or ceremony. In other words, the phenomenon of sacredness in the vast majority of interpretations refers to the form of preaching and observance of religious ritual.

The notion of "sacred texts" (Admoni, 1994) has become widespread in linguistics, covering practically all kinds of religious texts. V. G. Admoni (1994) refers to texts as sacred where they meet the criterion of availability of "a certain proportion of sacredness" (p. 97), i.e. these texts 
are characterized by the rigour of form and some remoteness from utilitarian language. This is due to the fact that sacred (actually religious) texts, being the result of revelation from above, are closed systems, according to V. A. Kukharenko's (2002) terminology (p. 63); i.e. they are final, complete and their elements are not subject to further development, removal or replacement. Defining the textual category of sacredness as one of the constitutive features of religious preaching allows asserting that this category should be understood as a set of distinctive characteristics with inherent sacred, transcendental designation, distinguishing the text of religious preaching among those in other spheres of communication.

Further, the lexical means for the realisation of the category of sacredness require thorough analysis. It is of common knowledge that there are vocabularies in a language that are frequently used in particular areas of communication, being rarely (if at all) applied in other spheres. A text of a Christian sermon is not simply a special type of text; being created by the addresser based on absolute faith differs from other texts by its lexical characteristics, namely, the active use of the vocabulary of particular sacral transparency.

\section{Groups of Sacral Vocabulary}

The texts of the sermons under study contain several groups of sacral vocabulary:

1. traditional religious vocabulary;

2. vocabulary borrowed from the Holy Scriptures;

3. common vocabulary, which acquires occasional sacral meaning in the context of the sermon.

The first group embraces the traditional religious vocabulary as a narrow conceptual and terminological subsystem, i.e., part of the English vocabulary, which expresses religious meanings and concepts. Such a vocabulary directly characterizes a religious text and is available in all types of religious sermon texts, regardless of the occa- sion and the addressee.

This group includes:

- The vocabulary denoting the symbol of Christian faith - the Triune God: God, Jesus Christ, Holy Spirit, the latter is most frequently used in the context of the Holy Trinity. It should be noted that the frequent use of the vocabulary for the designation of the symbol of faith has been recorded in all texts of the sermons under study, which is due to the great variety of nominations of the Holy Trinity: God-Lord, Father, Love (meaning "God is Love”). E.g. And when we have set this aside, we find that it is only in the little space that there is room enough for all of us - forgiven, welcomed, made inheritors of the divine fullness of life and joy that God longs to share with us. Behind the low door of the stable is infinity and more, an infinity of mercy and love. No straining our eyes to see a distant God, but a God whose fullness dwells in that space we are not small and simple enough to enter (Anglican sermon ${ }^{1}$ ).

Hereafter, the underline, bold highlights the samples of the illustrated group of sacral vocabulary; bold front marks other types of sacral vocabulary. This enables getting a general idea of the saturation of the Anglican and Neo-Protestant sermons with sacral vocabulary.

He is Lord, and he is King. We all want an inside source, a friend in high places, someone who can help us when we are in trouble. Sometimes reporters talk about a "highly-placed source" who gave them certain informati-

The material for our study - the sermons of Anglican and Neo-Protestant preachers - was recorded by the authors directly during Anglican services in Westminster Abbey, Southwark Cathedral, St. Pancras Old Church (London) and Protestant prayer meetings, held in Emmanuel Evangelical Church, GraceLife London, Hope London Central International Church, Reality Church London. Since our primary interest is aimed at the preacher's belonging to a certain confession, rather than a specific authorship, we considered it inappropriate to emphasize personalities, and therefore limited ourselves to marking passages from sermons as "Anglican sermon", "Neo-Protestant sermon". 
on. The higher the source, the closer you come to the seat of power. Since the Son is at the Father's right hand, we have a friend in heaven who dwells eternally at the throne of God. When we pray, we are talking to One who is at the very centre of all thing (NeoProtestant sermon). Jesus Christ - Saviour, the Son of God, Messiah: And this Son's character is "Wonderful Counsellor, Mighty God, Everlasting Son, Prince of Peace” Yes! His rule is characterised by everlasting justice and righteousness, instead of the ruthless greed and exploitation which prevailed when he was born and is prevailing now in our global village (Anglican sermon); Jesus Christ is the Agent of Creation and the Heir of All Things. He was there at the beginning, and he will be there at the end. And he is the Lord of everything in between. Truly he is the Alpha and Omega, the Creator, the Lord, the King (Neo-Protestant sermon).

- Vocabulary, indicating the main religious activities that can be loosely divided into:

a. general religious activities: to pray, prayer, the confirmation, liturgy, (holy) communion, mass, sacrifice, baptism, to baptise, faith, to believe, to preach, to sermonize; divine service, fast, lent, etc.: So what is the main point, well, we just heard about that in Romans. Baptism is one means by which God connects us to himself; God connects our story to his story. Romans says it so beautifully: Do you not know that all of us who have been baptized into Christ Jesus were baptized into his death? We were buried therefore with him by baptism into death, in order that, just as Christ was raised from the dead by the glory of the Father, we too might walk in newness of life. (Anglican sermon);

b. historical events and phenomena: Resurrection, crucifixion, revelation, Holy Communion.

It should be noted that such vocabulary partly depends on the theme of the sermon.
For example, if a sermon is preached in the period preceding Easter and on Holy Sunday itself, the religious and historical events and phenomena such as fast, lent, sacrifice, tomb, crucifixion, resurrection are more commonly mentioned; e.g. In our gospel lesson today, Mary Magdalene makes her way to the tomb to attend to Jesus. When she finds the stone rolled away from the tomb, she runs to bring it back with her Peter and the beloved disciple. The two men run back to the tomb, eager to see what Mary is talking about. When they arrive at the tomb, they see that Jesus is not there. They do not understand what they are seeing or what they are not seeing, and they simply return to their homes. They miss Easter. I find myself standing at the tomb with them on Easter morning, the tomb is empty - what does that mean? (Anglican sermon); At the crucifixion of Jesus, Peter, who had denied the Lord three times, was nowhere to be found. He was cowering in fear - hiding away somewhere, filled with shame and guilt. John stood by the Lord and was given responsibility for Mary, Jesus' mother. But after that, John must have gone to where Peter was, because Mary Magdalene found them together after seeing the stone rolled away from the tomb. She reported that Jesus'body had been stolen but gave no indication about a resurrection or anything. Luke's gospel records the reaction: that it was idle tales. They did not believe the women at all. We don't know exactly why, but the two bolted away and started running. Perhaps they worried that it was going to get light soon and that if caught during the day, they could face the same fate as Jesus. Maybe they felt a sense of responsibility to look after the body since they were Jesus' main men. It's possible they felt some guilt at not having the courage to ask Pilate for the body as Joseph of Arimathea 
and Nicodemus had done (Neo-Protestant sermon).

- Vocabulary denoting the essential attributes of the Christian faith: Bible (Holy Bible), Gospel, gospel reading, Scripture, carols, Heaven, hell, the throne of God; e.g. In today's Gospel, we heard Parables of the Lost Sheep and Coin, perhaps so familiar that we miss how radical it may have been to imagine God as a shepherd leaving behind ninety-nine sheep to seek the one, but even more, to imagine, God as a woman, turning her house upside down until she finds her precious coin (Anglican sermon); According to the Scripture, Noah found grace in the eyes of the Lord, and there were seven other members of his family that were saved out of the whole population (Neo-Protestant sermon).

- Vocabulary denoting church institutes: church body - meaning "the Church is the body of Christ"), Cathedral, temple, monastery, cloister etc.; e.g. Yet, at the same time, the ministry of a broken Church should not alarm or dismay us - paradoxically, it should encourage us that the Church in its life and ministry has always manifested brokenness. Foolish as we are, with all our human weaknesses and vulnerabilities, all our own brokenness, God chooses all of us who are baptised and calls us to journey with Him and to serve His people and His Church. Unfortunately, the fact that we are ultimately part of one Church is all too often overlooked. Just as Christ's body was broken on the cross, we continue to break His body, the Church, today when we reject and even persecute others because they worship God differently (Anglican sermon).

Since this work primarily reconstructs the communicative side of the sermon, which envisages not only the communion of the pastor with the congregation but also the congregation's convention for the meeting with and in the name of the Lord, the lexical units of the first group nominating the Holy Trinity should be scrutinized. The frequency calculation of the lexical units of the first group in different types of sermons has revealed a certain regularity in the use of the sacral vocabulary of this group, depending on the type of sermon (Table 1):

Table 1.

Frequency of Traditional Religious Vocabulary in the Sermons under Study

\begin{tabular}{||c|c|c|c|c||}
\hline \multirow{2}{*}{ Lexical units } & \multicolumn{2}{|c|}{ Anglican sermon } & \multicolumn{2}{c|}{ Neo-Protestant sermon } \\
\cline { 2 - 5 } & Number of uses & $\%$ & Number of uses & $\%$ \\
\hline \hline $\begin{array}{c}\text { to indicate the sym- } \\
\text { bol of faith }\end{array}$ & 780 & 20.4 & 504 & 34.7 \\
\hline $\begin{array}{c}\text { to indicate religious } \\
\text { and historical } \\
\text { acts/events }\end{array}$ & 1508 & 39.6 & 230 & 15.9 \\
\hline $\begin{array}{c}\text { to denote the attrib- } \\
\text { utes of the Christian } \\
\text { church }\end{array}$ & 804 & 21.1 & 115 & 7.9 \\
\hline $\begin{array}{c}\text { to designate church } \\
\text { institutes }\end{array}$ & 721 & 18.9 & 601 & 41.5 \\
\hline \hline Total & 3813 & $100 \%$ & 1450 & $100 \%$ \\
\hline \hline
\end{tabular}

It should be further noted that the relatively high percentage of the vocabulary used to refer to church institutes is explained by the use of the word church in both types of preaching. It is characterized by the most frequent use, firstly, due to its different interpretations in the sermon: church as a church institution in general, the Christian church (e.g. "Can anyone imagine that 
in the Apostolic period, the Christian Church would have been subjected to any kind of reproach...") and Church meaning the Church of England (e.g. "Unfortunately, we ourselves do not value our church..."), and, secondly, due to its active use in the attribute function (e.g. Church life, Church hierarchy, Church questions, Church bishops, etc.).

The data in the table reveals significant differences between the Anglican and the Neo-Protestant sermons in the frequency of use of sacral lexical units of different types. It should be primarily noted that despite the almost equal volume of the studied material, being - 72 Anglican sermons and 68 Neo-Protestant sermons (540 and 620 pages of transcribed text, respectively), Anglican sermons exhibit more than twice the frequency of sacral vocabulary than Neo-Protestant sermons (3813 and 1450, respectively). Anglican preaching is characterized by approximately equal percentages of vocabulary from the symbol of faith $(20.4 \%)$, indicating the attributes of the Christian church (21.1\%) and church institutions (18.9\%). However, the exception is the lexical units for the designation of religious and historical events, the percentage of their use being comparatively high (39.6\%). This can be explained by the fact that, normally, the texts of Anglican sermons repeatedly refer to a particular religious event described in the Gospel (for example, in the Sunday sermon preached during Lent, there were 23 incidents of the use of the word Lent emphasizing the importance and necessity of fasting on the eve of Easter).

The Neo-Protestant sermon is characterized by the frequent use of lexical units to refer to church institutes (as mentioned above, this is almost solely the word Church in quotations) $(41.5 \%)$ and the symbol of faith (34.7\%). This finding can be explained by the fact that during a Neo-Protestant sermon, preachers often turn to God with a brief prayer or question during their speech, thereby demonstrating a constant connection with Him. It is due to the frequent use of the words God, Jesus (Christ), Lord and Church that the overall percentage of the two subspecies of the vocabulary has proven to be so high.

The apparent process of desacralization observed in the Neo-Protestant sermons cannot be overlooked. This occurs, primarily, because of the presentation of sacred information through informal, conversational and everyday style, often inherent in Neo-Protestant sermons, occasionally replacing sacral lexical units with stylistically unmarked ones, which appears alien to the religious style and can be regarded as inadmissible in religious texts. An example is the Easter sermon, in which the phrasal verb to get up is used instead of the traditionally accepted verb to rise to signify the resurrection of Christ (to get up = to arise from bed or rise to one's feet) in the past tense, not always properly used (did not died), e.g. Consider this for a moment. Because Christ got up, He is alive today. He did not died and go to heaven as all of those believers who have gone on before us have done. No, He died, went to hell and freed some souls, and then went back. Jesus freed souls while He walked the earth and He freed them from hell after He died. After He got up He freed some more and is still freeing souls to this very day! Why is this important? In our lives when a Christian dies we have a funeral to say goodbye and celebrate their life. We reflect on the things they did for God in how they treated others. Everything we say about them is in "past tense" (Neo-Protestant sermon).

In addition, the desacralization of the presentation may occur even where sacral vocabulary is used. This can be discovered when a sacral lexical unit is used in an improper, sometimes obscene, sacrilegious context, which can distort the message's main idea. Two passages from the Neo-Protestant sermon can serve to exemplify the statement above. The first deals with the need for regular liturgical worship (Holy Communion), where the comparison is used to receive Communion and to have sex with your wife as one-line actions: I asked the pastor why they only receive Communion once a month, and he said he thought that helped keep it spe- 
cial. "Do you only have sex with your wife once a month to keep that special?" I asked. The second passage describes the wanderings of the Virgin and Joseph, who sought shelter before the birth of Christ; in it, the preacher ironically beats the fact of Our Lady's virgin birth: So Mary and Joseph are getting to stable. Joseph bangs on the door and asks, "Please, please let us in, my wife is pregnant". "That's not my fault", says the innkeeper. "And it's not mine either", says Joseph.

The second group of sacral vocabulary has been borrowed from the main sacred texts - the Old Testament and the Gospel. Basically, they are "idioms and aphoristic expressions that communicate emphatically "complete" thoughts (results and conclusions), conveyed emotionally, in a bright and original linguistic design" (Betekhtina, 1995, p. 21). The lexical units of this group include:

- intertextual realities denoting geographical locations related to biblical history: Jerusalem, Canaan, Gomorra, Sodom, Sinai, Gethsemane, etc.: Firstly, God listens to us. Our prayers are always heard. They may not always be answered in the way we want or expect them to be, but God is always listening. We don't have to be Moses on Mount Sinai for Him to hear us (Anglican sermon); There were a few friends of God during Jesus' time, but when we think that the population of Jerusalem alone at the time of the Passover was a million and that at Pentecost there was also a million people in that city, but only 3000 were converted, we say "What a vast harvest that was" (Neo-Protestant sermon);

- biblical proper names: Matthew, Luke, John, Paul, Peter, Mary Magdalene, Zachariah, Moses, Noah, Judas, Pilate, etc.: He wasn't there when Mary Magdalene, Peter and the beloved disciple came looking for him. His life for a moment was hidden in death (Anglican sermon); When Zachariah saw him, he was startled and was gripped with fear. But the angel said to him: "Do not be afraid,
Zachariah; your prayer has been heard. Your wife Elizabeth will bear you a son, and you are to give him the name John" (NeoProtestant sermon);

- zoosemisms; floral designations reflected in the biblical context: lamb, scapegoat, $B a$ laam's ass, golden calf, the lost sheep, a wolf in sheep's clothing, barren fig tree, tree of life, burning bush, olive branch, etc.: Now Jesus, on the cross, was supposed to be the scapegoat to end all scapegoats. And, if we believe that to be true, as we said a few moments ago in the Creed that we did, we have to stop looking for new scapegoats - bankers and politicians spring to mind for example (Anglican sermon); In today's Older Testament lesson, Moses interceded with God after He declared his intention to punish His people who had turned their backs on Him and worshipped the golden calf (Neo-Protestant sermon);

- biblicalisms containing an indication of a part of the body (somatism) and human physiology: the all-seeing eye, to wash one's hands, an eye for an eye, to keep as the apple of one's eye, by the sweat of one's brow, with blood and sweat, etc.: How hard is it for you to not seek revenge when another person does you wrong? Jesus tells us that we are to Love More, Give More, Do More, and Trust More, are you willing to take a stand for the kingdom of God? You have heard that it was said, "Eye for eye, and tooth for tooth. But I tell you, do not resist an evil person. If anyone slaps you on the right cheek, turn to them the other cheek also" (Anglican sermon); Pilate wanted to release Jesus but without any cost to him personally. He wanted to let him go, but without having to take a personal stand. He admired Jesus in a way, but not enough to believe in him. He yielded finally to private blackmail and public pressure. And so he sentenced Jesus to die. But in the final act of a tortured conscience, he took a bowl of water and washed his hands. It was an act the Jews 
would understand because it came from the Old Testament. In fact, it comes from Deuteronomy 21 where the Lord laid down a ceremony for the case of an unsolved murder. It involved washing your hands over a heifer whose neck had been broken. The ceremony meant, "He is innocent and so am I" (NeoProtestant sermon).

The third group of vocabulary that characterizes religious sermon texts is a rather heterogeneous set of vocabulary units, the boundaries of which are somewhat stratified, since this vocabulary belongs to the linguistic usage of everyday communication, however, acquiring sacred significance in the context of a religious sermon. Tokens such as life, deed, law, love, blood, death, soul etc., belong to such words. Each of these words in ordinary speech has a range of definite meanings. In a religious speech, which is metaphorical and figurative, these same words occasionally acquire a new meaning and enter the semantic field of religion. As it can be seen from the above examples, the vocabulary of the third group is widely used by the preachers in the sermon texts under study.

\section{Conclusion}

The above said suggests that being essentially a secondary form of sacred texts (the primary text is the Bible), the text of the sermon demonstrates the frequent use of the sacral vocabulary of three different groups: narrow conceptual and terminological vocabulary, which has religious sense and meanings, borrowings from sacred texts (the so-called biblicalisms), and vocabulary of everyday communication, which in the context of preaching becomes religious, and is included in the semantic field of religion on this basis. Different perception of nature and ways to realize the sermon in the Anglican and NeoProtestant churches is manifested in the peculiarities of the attitude towards the sacrality of the Word. The process of desacralization of the ser- mon, recorded in the Neo-Protestant sermons, occurs due to the contrasting use of sacred vocabulary in a stylistically reduced context, on the one hand, and the use of profane vocabulary to nominate sacred phenomena, on the other. Nevertheless, despite the differences in approaches to understanding the essence and methods of preaching between Anglicans and Neo-Protestants, it seems possible to identify general patterns of sacred vocabulary functioning in the sermons.

Thus the study of sacredness in preaching discourse is a new but not the only area of application of the theolinguistic approach to religious formations in language and speech. Such research lines as the theolinguistic interpretation of linguistic phenomena, the emergence and functioning of which is conditioned by religious factors; theolinguistic study of religious fiction, special religious literature; theolinguistic understanding of the influence of the language of religion on non-religious spheres of its application also seem to be promising and fruitful.

\section{References}

Admoni, V. G. (1994). Sistema form rechevogo vyskazyvaniya (System of the speech utterances forms, in Russian). Saint Petersburg: Russian Academy of Sciences, Institute of Linguistic Studies.

Betekhtina, E. N. (1995). Frazeologicheskie edenitsi s antroponimicheskim komponentom bibleiskogo proiskhozhdeniya $v$ russkom i angliiskom yazykakh (Phraseological units with an anthroponymic component of biblical origin in Russian and English, in Russian). In Bibliya $i$ vozrozhdenie duhovnoi kul tury russkogo i drugikh slavyanskikh narodov (Bible and revival of the spiritual culture of Russian and other Slavic peoples, in Russian) (pp. 20-31). Saint Petersburg: Petropolis.

Block, D. I. (2014). For the glory of God: Reco- 
vering a biblical theology of worship. Grand Rapids: Baker Academic.

Crystal, D. (2003). A dictionary of linguistics and phonetics. Harmondsworth: Penguin Books.

Gadomsky, A. K. (2005). Teoligvistika: istoriya voprosa (Theolinguistics: A history of the question, in Russian). Uchenye zapiski Tavricheskogo national'nogo universiteta, Filologiya (Scientific Note of TNU. Philology, in Russian), 1.18(57), 16-26.

Gössmann, W. (2002). Kulturchristentum: Religion und Literatur in der Geistesgeschichte (Cultural Christianity: Religion and Literature in Intellectual History, in German). Kevelaer: Butzon \& Bercker Verlag.

Koncharevich, K. (2012). K teoretiko-metodologicheskomu obosnovaniyu sopostavitel'noi teolingvistiki (na materiale russkogo i serbskogo yazykov) (On the theoretical and methodological substantiation of comparative theolinguistics (On the material of the Russian and Serbian languages), in Russian). In V. Belokapich-Shkuntsa (Ed.), 7 Mezhdunarodnyi symposium Dostizheniya i perspektivy sopostavitelnogo izucheniya russkogo i drugih yazykov (The $7^{\text {th }}$ International Symposium on Achievement and Prospects of a Comparative Study of Russian and Other Languages, in Russian) (pp. 14-22). Belgrad: Slavistichko drustvo.

Kucharska-Dreiss, E. (2004). Teolingwistyka próba popularyzacji terminu (Theolinguistics - An attempt to popularize the term, in Polish). In S. Mikołajczak \& T. Węcławski (Eds.), Język religijny dawniej $i$ dziś (Religious language in the past and today, in Polish) (pp. 23-
30). Poznan.

Kukharenko V. A. (2002). Interpretatsiya teksta (Interpretation of the text, in Russian). Odessa: Latstar.

Malinovich, Yu. M. (1998). Semantika egotsentricheskikh kategorii $v$ kontseptual'noi modeli estestvennogo yazyka (The semantics of egocentric categories in the conceptual model of the natural language, in Russian). In Problemi verbal'noi kommunikatsii i predstavleniya znanii (Issues of verbal communication and knowledge presentation, in Russian) (pp. 116-119). Irkutsk: IGPII.

Moser, K. (2019). Understanding religious experience: From conviction to life's meaning. Cambridge University Press.

Nazarov, V. N. (2004). Vvedenie v teologiyu (Introduction to theology, in Russian). Moscow: Gardariki.

van Noppen, J.-P. (2006). From theolinguistics to critical theolinguistics: The case for communicative probity. ARC (Montreal), 34, 47-65.

Shamarova, S. I. (2012). K voprosu o teolingvistike: tsel, zadachi, ojekt, metody $i$ osnovnye napravleniya (On the issue of theolinguistics: Goal, objectives, object, methods and main directions, in Russian), Filologicheskie nauki (Philological Sciences, in Russian), 27-35.

Wagner, A. (1999). Theolinguistik in Internationale Tendenzen der Syntaktik und Pragmatik (Theolinguistics in international trends in syntactics and pragmatics, in German). In Akten des 32 Linguistischen Kolloquiums in Kassel 1997 (Files from the $32^{\text {nd }}$ Linguistic Colloquium in Kassel 1997, in German) (pp. 507-512). Frankfurt am Main: Peter Lang. 